\section{ENCOURAGE THEM TO LEARN: CASE STUDY OF FICTITIOUS PRODUCT AND VIRTUAL MARKET IN MARKETING COMMUNICATIONS DEGREE COURSE}

\begin{abstract}
At the Faculty of Economics and Management at the Czech University of Life Sciences Prague (CULS Prague) a wide range of marketing courses are taught, covering many aspects of marketing theory. The curriculum of the majority of marketing courses consists of case studies and project work in teams. The students in their MSc. studies have five marketing subjects in total, and work with different teachers, though the same teaching approach and design (project teaching) is used. In this article, we present the results of a new design for the Marketing Communications course. In this case, students are engaged in designing a real package for a fictitious product, and to enter a virtual market using a wide range of promotional tools. The students then debrief the entire experience as consumers in that virtual market. The course uses a mix of traditional and contemporary teaching techniques in the field of marketing communications. It can be used in traditional or blended learning or adapted for online courses. The innovative course design has been shown to be a key factor to stimulate the students to learn, rather than simply study and repeat their lectures. The learning efficiency compares favourably with the original course design.
\end{abstract}

\section{KEYWORDS}

\section{Fictitious product, marketing curriculum, Moodle, promotion, virtual market}

\section{HOW TO CITE}

Švec V., Selby R. (2019) 'Encourage them to learn: Case Study of Fictitious Product and Virtual Market in Marketing Communications Degree Course', Journal on Efficiency and Responsibility in Education and Science, vol. 12, no. 3, pp. 66-74. http://dx.doi. org/10.7160/eriesj.2019.120301

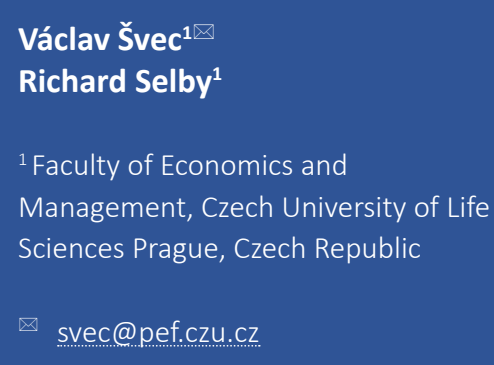

Article history

Received

August 10, 2018

Received in revised form

March 24, 2019

Accepted

September 2, 2019

Available on-line

October 4, 2019

\title{
Highlights
}

- New course design using theoretical knowledge and practical skills.

- Qualitative students' evaluation of the proposed course design.

- Innovative approach in course design does effect the study outcomes.

- Course designed fully complies with Kolb' s learning cycle.

\section{INTRODUCTION}

Education today increasingly differs from that at the end of $20^{\text {th }}$ century. We are living in a time of growing implementation of modern information and communication technologies (ICT) into the education of children and adults of all age groups (Hruby, 2008). This trend is called the "Read-Write Web", which is a social software, where everyone publishes resources on the web using simple and open, personal and collaborative publishing tools (O'Reilly, 2005). Cachia (2008) defined "Social software" as those applications that enable a wide range of interaction, collaboration and sharing between users. These include applications for blogging, clipping, instant messaging, forums, web directories, social bookmarking, social networking, multimedia sharing and cataloguing, social cataloguing, social citations, and social gaming, virtual words, wikis, eLearning, etc. Social software applications are based on digital media and digital technologies. As "Digital media" we include any media that exists in a computer-readable format, and can reside on a local device (CD, DVD, Blue Ray, or hard drive), or remote location (website) (Caputo, Wolf and Borho, 2006). This paper deals with curriculum development, therefore, we will only be considering the role of digital media in education here.

According to Watson and Pecchioni (2011), digital media in education are either demonised or viewed as the panacea for curriculum ills. Hedberg (2011) sees the possibility of using 
digital media in education as a unique challenge, especially in producing positive learning outcomes, which, in terms of efficiency and usefulness, also confirms the findings of Aberson et al. (2002) and Law, Lee and Yu (2010). On the other hand, Dillenbourg (2000) understands that challenge as reaching a deep understanding of the relationship between technological choices and teaching processes. A similar view of this problem is presented by Mayer (2005), who states that the question "What can we do with multimedia?" is adopting a technology-centred approach that is doomed to fail. This is also confirmed by Young (1995), Huddleston and Unwin (1997), and Joshi et al. (2003), who all say that the teacher (or technology) cannot be in the central position of teaching, but it must be the student. The teacher nowadays has evolved into a "manager of education" or "facilitator", and technology becomes a medium, not the central point. Therefore, the question leading us to a student-centred approach, with proper use of digital media, should be how, or whether, to adapt digital media designs to help students more (Mayer, 2005).

There are several ways to answer Mayer's question. One of them offers the traditional methods of learning and education enhanced with new forms and learning methods, using digital media (Polackova and Jindrova, 2010). This is supported by Dillenbourg (2000), who sees the virtual learning environment as not only integrating a variety of digital media, but also integrating all the physical tools that can be found in a classroom (Dillenbourg, 2000: 12):

- A variety of non-computerised learning resources: physical tools, instruments, books, etc.

- A variety of interactions that are not computer-mediated: face-to-face discussion among students, lectures by the teacher, group discussions, including traditional media such as letters, TV, phone, fax, etc.

- A variety of activities that are not computer-based: field trips, role playing, etc.

So, according to Dillenbourg (2000), there is no need to draw a boundary between the physical and virtual worlds; the key is to integrate them, not to separate them.

The objective of this paper is to introduce the curriculum of the Marketing Communication Course. As a secondary objective, we seek to analyse whether there are statistically significant differences in study outcomes between different types of course designs.

\section{MATERIALS AND METHODS}

The term "curriculum" does not have a commonly agreed definition. Fraser and Bosanquet (2006) distinguish four meanings of the term curriculum: (1) the structure and content of a subject; (2) the structure and content of a programme of study; (3) the students' experience of learning; (4) a dynamic and interactive process of teaching and learning. For the purposes of this paper, definition (4) "the process of teaching and learning" has been chosen, together with definition (3), "the impact on the students' experience of learning" on the course level.

\section{Process of teaching and learning}

The methods used in the description of the teaching and learning process are analogy, observation, analysis, synthesis, modelling, and abstraction. The methods of analogy and modelling are used for developing the course design and inventing the plot, and for setting up the context and rules of the tools, which are used.

A pilot run of the design of the course was tested with students of the Marketing communication course taught in the spring semester of the academic year 2013/2014 at the Faculty of Economics and Management in the Czech University of Life Sciences in Prague. There were two different learning designs of the same course's syllabus of Marketing Communication. The Marketing Communication course was taught in parallel in two different course designs: (1) course design with virtual market and (2) live case studies course design. The course was attended by 240 students in total. Each class was visited by a maximum of 20 students. The students had all the basic information about the two different course designs in advance, and they made their own decision which to attend (self-selection). This process ensured the starting balance of preferences in both compared designs. The students divided into seven classes with virtual market course design, which 136 students attended, where 98 (72\%) students were females and $38(28 \%)$ males. On the other hand, six classes with the live case studies course design were attended by 104 students, where $62(60 \%)$ were females and $42(40 \%)$ were males. Overall, the student group comprised 160 women and 80 men.

\section{The impact on the students' experience of learning}

In this paper, besides a description of the course structure, the impacts of the course curriculum on the students were also studied. Interviews were conducted at the end of the semester to find the students' perspectives, and their evaluation of the course design. A set of open questions was developed, addressing topics such as students' engagement, teaching process, students' learning outcomes, and likes or dislikes of the course.

To find how students evaluated the virtual market course design, all students who attended this course design $(n=136)$ were asked to complete a short evaluation after the course and examination period were finished. Students evaluated the course design on a scale of: 1 - excellent, 2 - very good, 3 - good, 4 - poor, and 5 - terrible. Forms were anonymous, all students were asked to participate, and 129 forms were completed and analysed. The popularity of the virtual market course design, and also the impact on the students' learning outputs were investigated. As the benchmark for the evaluation of the learning efficiency of the students attending the virtual market course design, we used the usual form of the course design in the form of live case studies. The comparison between the live case studies course design (104 students) and virtual market course design (136 students) is based on the students' ratings. The comparisons were made using statistical analyses, where Pearson's $\chi^{2}$ and Maximum Likelihood $\chi^{2}$ tests were applied (Hendl, 2015). 


\section{The Marketing curriculum background}

The aim of the Marketing communication course is to provide students with an understanding of the basic objectives, principles, and processes of marketing communications. The course consists of lectures, workshops, and students' teamwork, all with the support of digital media of various forms. The lectures are focused on the theoretical issues of marketing communications, together with examples of practical applications, short videos, and discussions with the students. In contrast, the workshops are designed as sessions of training in practical skills, where students deal with practical tasks from different fields of marketing communication, evaluate their own work, mutually share and discuss their advances, and are methodically guided during the development of marketing communications' skills. Lectures and workshops are supplemented by e-learning activities in the Moodle (Modular Object-Oriented Developmental Learning Environment) Learning Management System (LMS), where resources, forums, lessons, wikis, and workshops were used as basic tools for skills development courses, according to Cole and Foster (2007).

The course of Marketing Communication builds on the Marketing Fundamentals course and is followed-up by these courses: Marketing Research, Strategic Marketing, and Global Marketing. As the students enter this course with the basic knowledge of marketing principles from their previous course (Marketing Fundamentals) and continue to study different marketing issues in their later courses, the Marketing Communication course focusses on teaching the basic principles and tools of marketing communication. At the end of the semester, students should demonstrate an understanding of various communication tools and techniques, their use, planning and control in the marketing context.

\section{Description of Virtual Market course design}

There is a maximum of 20 students in the classroom. Students are divided into five teams, each team consisting of a maximum of five members. As there are twelve weeks in the semester, we have twelve workshops and six lectures. The lectures are delivered every second week. During the lectures, the theoretical backgrounds of the promotion and promotional mix are introduced. The workshops are divided into two categories - explanatory and advisory workshops. The overall view of the lectures and workshops in the course is shown in Table 1. Both the lectures and workshops last for 90 minutes.

\begin{tabular}{|c|c|c|c|}
\hline Week No. & Topic of the lecture & Type of workshop & Workshop topic / task \\
\hline 1 & \multirow{2}{*}{ Promotion in marketing mix. } & Explanatory & Product's package development \\
\hline 2 & & Advisory & Product's package development \\
\hline 3 & \multirow{2}{*}{ Public relations } & Explanatory & Press release \\
\hline 4 & & Advisory & Press release \\
\hline 5 & \multirow{2}{*}{ Advertising } & Explanatory & Story board \\
\hline 6 & & Advisory & Story board, video making \\
\hline 7 & \multirow{2}{*}{ Sales promotion } & Explanatory & Plan of sales promotion \\
\hline 8 & & Advisory & Plan of sales promotion \\
\hline 9 & \multirow{2}{*}{ Personal selling } & Explanatory & Personal selling proposal \\
\hline 10 & & Advisory & Personal selling proposal \\
\hline 11 & \multirow{2}{*}{ Integrated marketing communication } & Explanatory & Virtual market \\
\hline 12 & & Advisory & Results from virtual market competition \\
\hline
\end{tabular}

Table 1: The structure of the course

\section{Explanatory workshops}

As the lectures are once in two weeks, the explanatory workshops follow the topic of the previous lecture and explain the topic in more depth in a practical way. During the explanatory workshop, students are always given a task within the lecture topic. The general scheme of the explanatory workshop is: explanation of the problem $\rightarrow$ task introduction $\rightarrow$ task clarification $\rightarrow$ teamwork $\rightarrow$ independent teamwork. The aim of the explanatory workshop is to brief students what to do, and to be sure they are not lost within the task. At the end of the explanatory workshop they should leave the class with a clear idea of their next procedure in their minds. After the explanatory workshop the students work on the task on their own in the teams.

\section{Advisory workshops}

The advisory workshops always follow the week after the explanatory workshops. These are used for the students to share their task development with each other and with the lecturers, with the possibility of improving the result. The general scheme of the explanatory workshop is: each team presents its unique draft of the solution $\rightarrow$ brainwriting $\rightarrow$ sharing the ideas, comments, and suggestions with each other. The lecturer is also involved in the process of brainwriting and sharing, in the role of facilitator.

\section{Support from the learning management system}

The Moodle learning management system (LMS) is used throughout the semester. It is used for sharing the lectures, content of explanatory workshops, and for uploading finished tasks from each team. There is a time limit for each task (packaging, press release, storyboard and video, sales promotion proposal, and personal selling proposal), which ends with start of the explanatory workshop for a new topic. In this way, the ongoing work of the students across the whole semester is arranged, thus avoiding the tendency to wait until 
the last minute to complete the main task (a presentation for the virtual market).

\section{Topics of the workshops}

Topics of the workshops are scheduled in a particular sequence, which is shown in Figure 1.

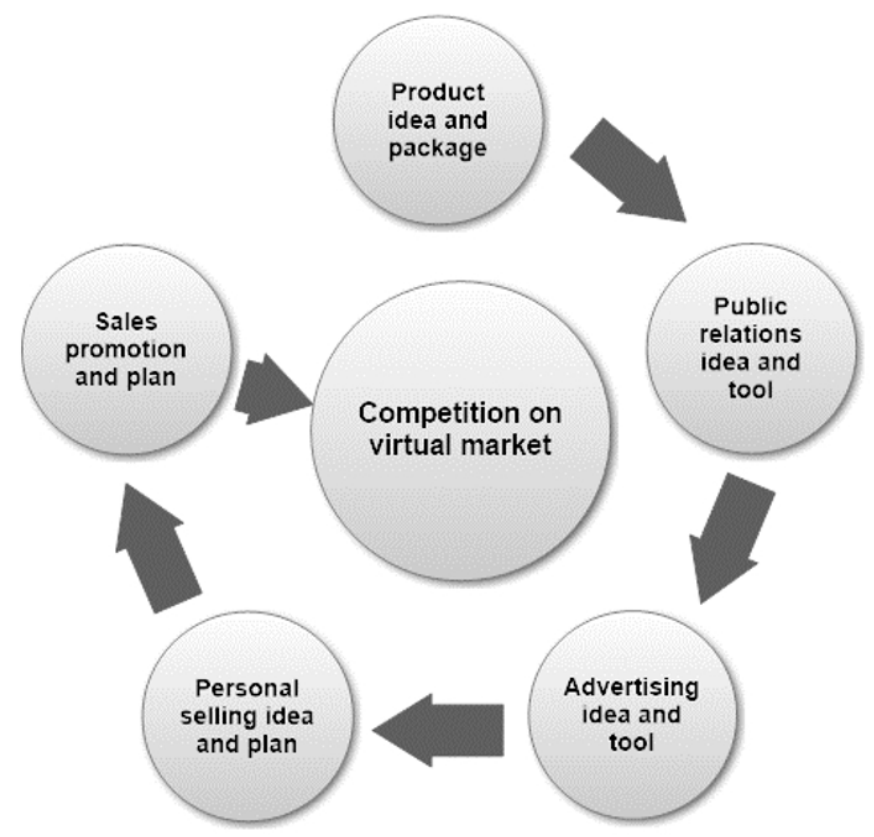

Figure 1: The sequence of workshop topics in course design with virtual market

As the first topic, the students are introduced to the Product's idea and package development, and this assessment works as a motivation and creativity booster for the students. The special topics then follow: for the field of public relations it is the press release and media list, in the field of advertising it is the storyboard and producing the video advertisement, in the fields of personal selling and sales promotion we want students to make a proposal of the plan. The final task to which all previous tasks are orientated is the presentation of the students' promotion on the virtual market. As a background process of these topics and their sequence, we want students to go through five essential stages (Edmondson, 2013):

1. Aim high,

2. Team up,

3. Fail well,

4. Learn fast, and

5. Repeat.

\section{Product's package development}

The $1^{\text {st }}$ (explanatory) workshop consists of an explanation of the importance of packaging for the product promotion and for the game, which will involve the students in the process of marketing promotion. The game helps us to engage the students' motivation. For this purpose, the game "Design the Box" (Gray, Brown and Macanufo, 2010: 161) was reworked. In this game teams get the task of making packaging for the imaginary product. The product might be anything they are able to think up. It might be an already-existing product, something waiting to be discovered, or even a product which has not or would not even ever exist. 'By imagining the package for their idea, the teams make decisions about important features and other aspects of their vision that are more difficult to articulate.' (Gray, Brown and Macanufo, 2010: 161). The students are given blank white or brown cardboard boxes. From these boxes they create the professional packaging for their imaginary products with all legal requirements according to law in the European Union. They can use any equipment, such markers, craft papers, stickers, tapes, images, etc. The process of creating the package box is very important for the course. It is the start of students' creative thinking. It is a connecting element for their enthusiasm, as they will discover they have no borders (except ethical and moral). It is also a great asset to their teamwork, as it is their first mutual output and they all are always very proud of it. They can also imagine their product and its features better, which is also important for the following workshops. During the course, we use this game as a focusing device (Gray, Brown and Macanufo, 2010), as students use the developed box in all workshops to remind them of their vision of the product and its characteristics. This idea is supported by Hackbert (2006), who says it is possible to use some teaching methods as a "hook" that enables them to engage and motivate students to learn. Edmondson (2013) mentions the importance of emotions as a motivator and reference point to return to in difficult times.

By the end of the workshop, several of the teams will still not know what product they should choose. This does not matter. The main goal, before the workshop ends, is to make sure all teams know that during the next workshop (which will be an advisory one) they will have to present at least their idea of the product and its packaging proposal.

At the beginning of the following advisory workshop, each team presents its idea of the product and its packaging. After each team presentation there is a discussion between all the teams and the lecturer. When all teams are done with their presentations, the brainwriting session starts. In this session, each team sums up the ideas, comments, or suggestions for other teams. During the brainwriting session, the proposals for the products' packaging are circulating around the classroom, so each team can analyse in depth each packaging from other teams. The lecturer does the same. When the brainwriting session is over all the teams have five lists of comments. It is up to each team whether they use the advice of the others or not. The advisory workshop ends with the repetition of the task and deadline for it to be uploaded onto the Moodle LMS.

\section{Following workshops' topics}

During each of the workshops' topics, students gain professional knowledge by means of "learning by doing". The topics are: for the field of public relations it is the press release and media relations, in the field of advertising it is the storyboard and making the advertising video, in the fields of personal selling and sales promotion we want students to know how to plan these activities.

The explanatory workshop for the field of public relations starts with an explanation of the basics of media relations, and continues with the press release, its characteristics, and ways to write a press release and produce a press kit. Then we let students work on their press release for their fictitious product. 
The advisory workshop starts with the presentations of situations for which press release is made, various press release proposals follow. After discussion about each proposal the brainwriting session starts, where each teams' press releases circulate the classroom, so each team can analyse the content in depth. After the brainwriting session, teams deliver the lists of comments to the particular teams, so each team has five lists of comments to their press release proposal.

The explanatory workshop for the advertising begins with the analysis of advertisements, description of components which the advertisements consist of, explanation of how an advertisement is formed, storyboard concept, ways to do storyboards, and examples of storyboards. After this introduction, students are asked to do their own storyboards for the fictitious product they possess. At the beginning of the advisory workshop students present their proposals of their storyboards. After discussion about each proposal the brainwriting session starts. The proposals circulate the classroom, so each team can analyse the content in depth and make a list of comments. Teams deliver the lists to each other, so at the end each team has five lists of comments to their proposal of storyboard.

Explanatory workshops for personal selling and sales promotion have almost the same procedure. We start with the explanation of the field tools and how to make a plan in sales promotion and personal selling. After that the students start their teamwork on planning their own sales promotion and personal selling for their fictitious product. The advisory workshops always start with the presentations of the students' proposals, followed by discussions, and brainwriting sessions with proposals' circulating the classroom and the exchange of lists. When all topics are explained, and all tasks are completed and uploaded to the LMS, we can start with the competition on a virtual market.

\section{Competition on virtual market}

During the whole semester, we use Moodle as the Course Learning Management System. For the course design with virtual market we use the Moodle "Workshop module" with its' system and forms, which allows the students to evaluate each other. In the opinion of Cole and Foster (2007) the workshop module is the most complex tool available in Moodle. 'Workshops are designed so a student's work can be submitted and offered for peer review within a structured framework. Workshops provide a process for both instructor and peer feedback on open-ended assignments, such as essays and research papers. There are easyto-use interfaces for uploading assignments, performing selfassessments, and peer reviews of other students' papers' (Cole and Foster, 2007: 95).

In practice, this means we have about 34 teams, each team uploads its promotional mix within the defined time frame. In the next time frame, they evaluate other teams' promotional mix. At the moment the time frame expires, the workshop module itself calculates the weighted score for each team and makes the final rating public with achieved scores and evaluation results.

Students know from the beginning of the course, that there will be virtual competition. They also know all the conditions. The process of the competition on virtual market is shown in Table 2.

\begin{tabular}{|c|c|c|c|c|}
\hline 1. Setup phase & 2. Submission phase & 3. Assessment phase & $\begin{array}{l}\text { 4. Grading evaluation } \\
\text { phase }\end{array}$ & 5. Concluding phase \\
\hline $\begin{array}{l}\text { 1. Set the workshop } \\
\text { description. } \\
\text { 2. Set the workshop } \\
\text { terms. } \\
\text { 3. Provide instructions. } \\
\text { 4. Edit assessment form. }\end{array}$ & $\begin{array}{l}\text { 1. Publish submissions } \\
\text { deadline. } \\
\text { 2. Submissions input. } \\
\text { 3. Allocate submissions. }\end{array}$ & $\begin{array}{l}\text { 1. Open for assessment. } \\
\text { 2. Publish assessment } \\
\text { deadline. } \\
\text { 3. Assessments input. }\end{array}$ & $\begin{array}{l}\text { 1. Calculate assessments } \\
\text { grades. } \\
\text { 2. Publish the ladder. }\end{array}$ & $\begin{array}{l}\text { 1. Provide the conclusion } \\
\text { of the activity. }\end{array}$ \\
\hline
\end{tabular}

Table 2: Process of the competition on virtual market - LMS point of view

The view of the Learning Management System on the phases of Virtual Market shows five stages. The teacher must be active only in the setup phase and the concluding phase. All the other phases are performed by the system (controlling of deadlines, the phases switching, calculating grades, publishing the ladder), or students (uploading files, evaluating the proposals). The process of competition on virtual market from the students' point of view is shown in Table 3 .

Although students perceive the process of competition on virtual market as one phase - the last one in Table 3 - the truth is that the process consists of four phases. The starting phase is the part where the students start to be drawn into the process of marketing communication because of their own ideas which they share, thus quickly transforming the group of individuals into a team. Edmondson (2013) divides this phase into two: aim high (choose the highest aims you can) and team up. The next phase is the phase where students prepare their promotion tools - it takes eight workshops, in which students discuss their ideas and have their opportunity to find whether their ideas might be accepted or not, and to rework it: "fail well, learn fast", according to Edmondson (2013). In the phase of preparation for the competition on the virtual market, the students consider making changes in their promotion tools, they should recall all the information and knowledge they have, or repeat (Edmondson, 2013). The process of competition on the virtual market itself is again the composition of all the phases according to Edmondson (2013), and it is the final process for students as they go through and evaluate the projects of the others - they should look up identical and different, compare, etc. The competition on virtual market serves as a social game with its competitive character, but it is also repetitive learning for students. As they evaluate as a team (each team has only one vote for each evaluated promotional mix), they have to communicate all the issues within the team first. This cycle ensures team communication and repetition of what they have been taught during the course.

As students evaluate the other teams' promotional mixes, they have guidance in the form of a scoring form - see Table 4. 


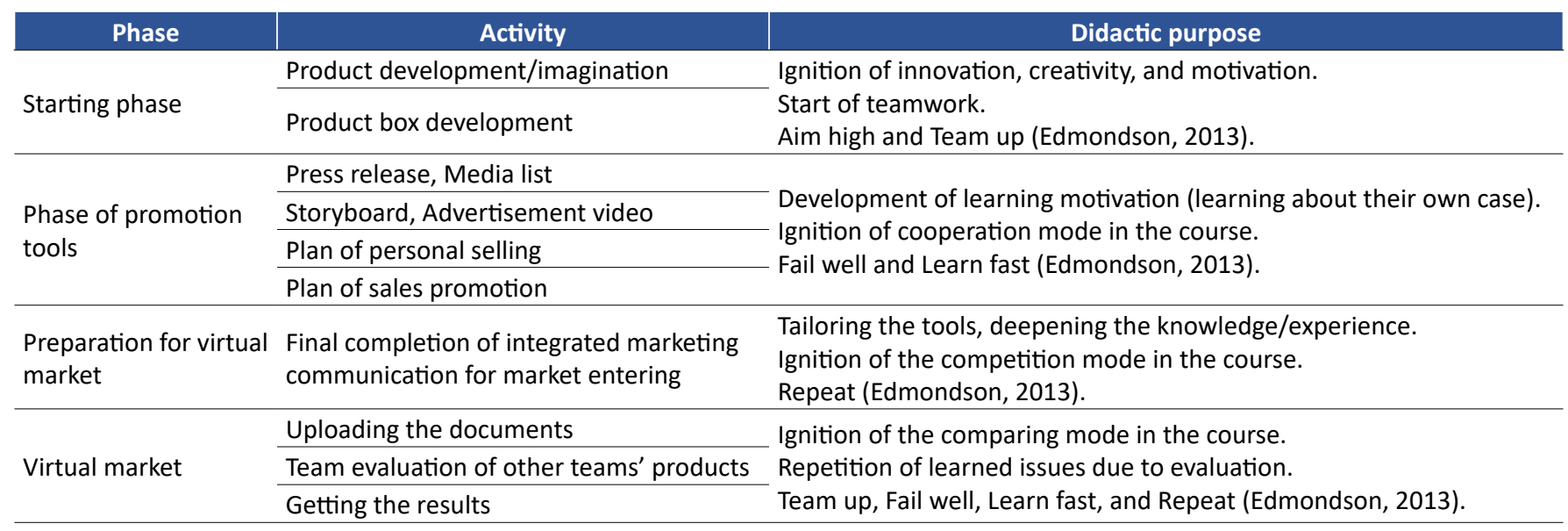

Table 3: Process of competition on virtual market from the view of students

\begin{tabular}{|c|c|c|}
\hline Class of aspects & Evaluation of the & $\begin{array}{l}\text { Maximum } \\
\text { of points }\end{array}$ \\
\hline \multirow{3}{*}{ Aspects evaluating product/packaging: } & innovativeness of product idea & 10 \\
\hline & packaging functions & 10 \\
\hline & product meeting the customers' requirements/needs & 10 \\
\hline \multirow{2}{*}{ Aspects evaluating public relations: } & press release criteria & 10 \\
\hline & presented media list (media targeting) & 10 \\
\hline \multirow{2}{*}{ Aspects evaluating sales promotion: } & suitability of used tools of sales promotion & 10 \\
\hline & innovativeness of using sales promotion tools & 10 \\
\hline \multirow{2}{*}{ Aspects evaluating personal selling: } & suitability of used tools of personal selling & 10 \\
\hline & innovativeness of using personal selling tools & 10 \\
\hline \multirow{3}{*}{ Aspects evaluating advertising: } & suitability of chosen type of advertisement & 10 \\
\hline & suitability of appeals used in advertisement & 10 \\
\hline & suggestive power of the advertisement & 10 \\
\hline Aspects evaluating integrated marketing communications & information consistency between used promotion tools & 30 \\
\hline Maximum points for assessment (total) & & 150 \\
\hline
\end{tabular}

\section{Table 4: Scoring guide}

Good scoring guides ask specific questions about the work being evaluated (Cole and Foster, 2007). The scoring guide for competition on the virtual market contains specific questions on each of the 13 aspects in Table 4.

\section{RESULTS}

Sufficient attention must be paid not only to the course design and the learning context, but also to what was in the mind of individual students which motivated their learning process (Law, Lee and $\mathrm{Yu}, 2010$ ). We therefore investigated the students' expectations from the course, and also examined the evaluation of the course.

\section{Students' expectations}

To find out what the expectations from the course design with virtual market were, we interviewed the students. The interviews were conducted at the end of the semester, so the students were able to express their early expectations before the course even started and compare it with reality. The students' expectations were linked to the nature of the marketing communications field like, for example, the presence of creativity in the course design "I hoped there would be room for our ideas and solutions."
Some students also expected only theory in the course: "Reality exceeded my expectations. I expected the classical theory of 4P's and a lot of boring lectures. I really enjoyed the realism of the course. It is the first time I felt the lectures and workshops were really real-life not only theoretical background from the books." or "I thought the course will be only theoretical. Developing the product was really genuine and interesting." There were, however, students who also expected more practice during the course: "I expected to learn the basic tools of marketing communication in practice." From the interviews conducted, it turns out that students expected an interactive course with a lot of creativity, not only theory, but practical activities within the field of marketing communications, teamwork, a chance to try marketing communication tools, to experience some fun, and to learn something new, which they might use in their future professional life.

\section{Students' evaluation of the course design with virtual market}

We also asked students for their evaluation of the course design with virtual market. First, we let them speak during interviews, and then we let them complete a short evaluation form. The outcomes from conducted interviews were interesting, receiving positive responses 
in the majority of cases: "I evaluate this course as one of the most engaging courses I experienced. The tasks we were doing were different and more interesting than in other courses. I liked the system of teaching, where not only the teacher explains stuff but we were also allowed to discuss the tasks' outcomes or evaluate the work of the others." or "I liked this subject very much, it was the first one I was looking forward to, there was fun during the tasks'fulfilment, and thanks to the practical tasks I remember everything." In addition, there were other comments, which show that the course design touched the students: "The system of the course was interesting. I liked it. I experienced such a course design for the first time in my student's career; finally, there was something of action!" Another opinion: "I really appreciate the design of the course, where we chose our own product and we did all the marketing communication stuff around it. I felt very good in our team and I have a feeling all team members did enjoy developing the product. I also had a feeling that the other groups were also enjoying the course work."

Naturally, we also obtained some negative responses to the course design with virtual market: "The evaluation form does not have to be so extensive (13 criteria). Time required to complete evaluation form was unexpected in the last week of the semester." or "The virtual market's system would need some modifications to work better: 1) strictly follow the rule about the group and product naming. 2) The best and the worst ratings should be removed as the extreme values so the evaluation would be close to average. 3) To stress that finishing the evaluation form at once is necessary or the form will close and it will not be able to continue". The negative responses contained the problem, but also gave an indication how to solve it - or even the full solution to the situation. This confirms the students' passion for the course design and the higher level of their motivation.

When the Marketing Communication course designed as virtual market was finished, the students had a chance to evaluate the course with the grades in the way teachers do. As can be seen in Figure 2, the students evaluated the course in five categories: excellent, very good, good, not appropriate, and terrible.

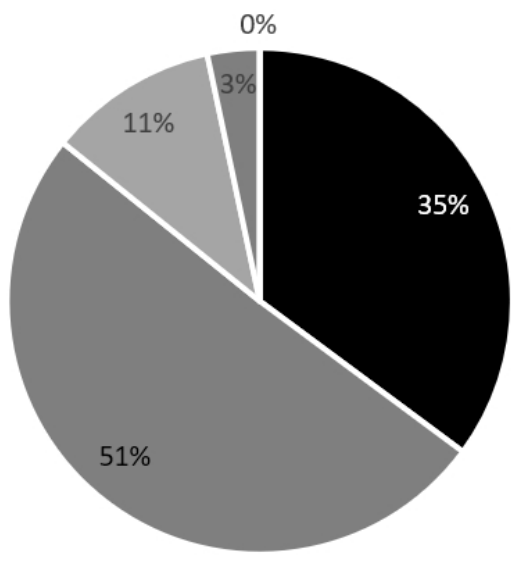

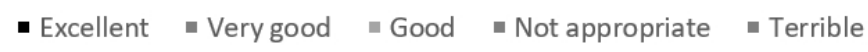

Figure 2: Students' evaluation of the Marketing Communications course designed as virtual market
The results show that the students liked the course design with virtual market a lot $-86 \%$ of the students evaluated it as either excellent or very good, $11 \%$ of the students were not so enthusiastic, and 3\% were disappointed by the course design, but nobody thought the course design was terrible. Compared to other courses with which the authors have experience, such as the Management course, taught in the same semester and involving the same students, course design with virtual market rules. Even though the design of the Management course is quite innovative, and may be taken as the quality standard, the students' evaluation of the course shows that only $72 \%$ of them rated it as either excellent $(11 \%)$ or very good, whilst $25 \%$ rated it as good, and 3\% thought it was not appropriate (Svec, Ticha and Kaderakova, 2011). As before, no one thought the course was terrible - it shows the distinction in the students' perception of the course design with virtual market especially in category excellent (increase of $24 \%$ of students) and in category good (decrease of $14 \%$ of students). These shifts indicate students' increased interest in the course design with virtual market.

From the students' point of view, it is obvious that they enjoyed the course design with virtual market. The interviews also revealed some verdicts suggesting the positive impact of the course design to the learning outcomes, e.g.: "... and thanks to the practical tasks I remember everything." Therefore, we might ask whether the design of the course really has any positive impact to the study results in general.

\section{Comparison of study results}

We teach the Marketing Communications course in parallel with another which has a different course design - live case teaching. Live case studies course design, according to Simkins (2001), we use in cooperation with external companies whose problem or issue in the field of marketing communication has not yet been resolved, and the company is seeking input from the students to assist them in making a decision.

To find out the impact of the course design with virtual market to the learning outcomes of students who attended it, the students' grades were taken from both types of courses designs, and comparative graphs were computed (Figure 3 ).

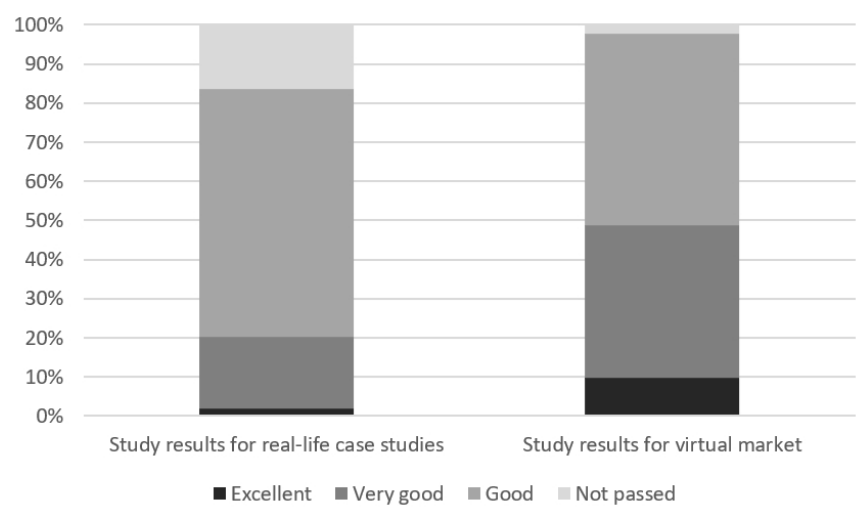

Figure 3: Study results in live case studies and virtual market course design

We used a four-point scale for grading as commonly used at the university: excellent, very good, good, and failed or not passed. Even so, it is apparent from the charts that the study results 
differ between these two groups of students. The conducted statistical test (Table 5) confirms this result.

\begin{tabular}{|c|c|c|c|}
\hline \multirow{2}{*}{ Statistics } & \multicolumn{3}{c}{ Variables: Grades $\mathrm{x}$ VirtualM $\mathrm{x}$ LiveC } \\
& $\chi^{2}$. & $d f$ & $\boldsymbol{p}$-value \\
\hline Pearson's $\chi^{2}$ & 31.2104 & 4 & .0000 \\
\hline M-V $\chi^{2}$ & 33.6515 & 4 & .0000 \\
\hline
\end{tabular}

Table 5: $\chi^{2}$ test of study results

The null hypothesis for Table 5 says: There is not a statistically significant difference in study results between the classes with live cases teaching and classes with virtual market design. The value of $\alpha$ is 0.05 . As the $p$-value is less than the $\alpha$ value, we can say that there is a statistically significant difference in study results between the classes with live case studies and classes with virtual market.

\section{DISCUSSION}

The finding presented in the charts in Figure 3 shows the statistically significant difference in study results between the two course designs: live cases and virtual market. In the finding of possible cause, we have to say, that currently there is no agreement in contemporary literature, as to which student-centred method brings more efficient study outputs. Simkins (2001) believes that the live case learning requires the students to apply even deeper intellectual thinking, and as a result, achieve greater wisdommore so than other pedagogical techniques. On the other side Hawrylyshyn (1967), who divides individual teaching methods focused on learners according to effectiveness of learning, or Merseth (1991), see the case method as effective especially for diagnosing problems, but of average effectiveness in making decisions.

There are also available the results of the research conducted at CULS Prague by authors Svec and Kaderabkova (2010) who found there is no statistically significant difference in study results coming from live case teaching and project-based teaching. The difference between the results might therefore lie in the context or focus in which the research had been conducted. Authors Simkins (2001) or Svec and Kaderabkova (2010) are focused on a particular teaching technique, but the course design with virtual market comprises of several techniques and, therefore, has a wider impact. This statement is supported by several authors who have evidenced the advantages of merging traditional classroom learning methods with experiential learning methods such as team-projects combining several courses, (Bobbitt et al., 2000), case-based courses (Blackmon, Hong and Choi, 2007), classroom projects (Camarero, Rodriguez and San Jose, 2009), semi-structured classroom activities (Hamer, 2000), and live cases (Elam and Spotts, 2004).

The explanation for the differences seen in Figure 3 may not only be due to the variety of teaching methods used; there is also another difference between both course designs: the overall learning process. Kolb (1984) gives the most detailed description of the overall learning process. Moreover, the author (Kolb, 1984) identifies four components in the learning process: affective (emotion), perceptual (perception), symbolic (process of thinking and cognitive abilities) and behavioural (actions). As in both courses designs the students learnt from their own experience, only in the virtual market design were they able to go through all four components of learning by Kolb (1984). In the words of Kolb and Kolb (2011), the students (in the virtual market design) thus touched all bases - that is, they lived, watched and reflected, thought, acted - in a recursive process that responds to the situation, and what can be learned in that situation. Students from the live case studies design were not able to track the impact of their decisions in the real situation. Therefore, they were not able to make any final reflection needed for their learning. Students from the live case studies course design were not able to learn Kolb's whole learning cycle.

With its placement in the programme curriculum, the Marketing Communication course is in its nature an introductory overview course, whose primary goal is to expose students to the basic concepts and vocabulary of this field of study. It is one in which the students develop a basic conceptual structure that serves as a foundation for more advanced courses (Cole and Foster, 2007: 196). However, as Cole and Foster (2007) stated, there is a basic problem with these types of courses - students may not be engaged by long lectures or vast texts. According to Cole and Foster (2007) students might be more interested in the course if they had the opportunity to apply basic concepts learned. This is what ensures skill-development, where students repetitively apply the important skills (Cole and Foster, 2007).

The virtual market course design unites both types of courses - that of introductory overview course, and also of skills development course, and due to the variety of activities, teaching methods used, and of full use of Kolb's learning cycle it has a positive effect on the students' study results. Based on the results of our research and our personal experience, we would recommend using the student-centred methods following the full process of the Kolb learning cycle.

\section{CONCLUSION}

The objective of the paper was to introduce the curriculum of the Marketing Communication Course. As a secondary objective, we sought to analyse whether there are statistically significant differences in study outputs between different types of course designs. We introduced our new approach to Marketing Communication teaching within the virtual market. Virtual market is both the introductory and development type of course design, which uses the experiential learning approach with a fully used cycle of learning according to Kolb and Kolb (2011). The conducted research showed the statistical differences in the study outputs of both course designs. As there are many research differences assessing the effectiveness of different teaching approaches, we will focus our future research on linking a coherent approach to the learning cycle and study outcomes.

\section{ACKNOWLEDGEMENT}

This article was created with the support of the Internal Grant Agency (IGA) of the FEM CULS in Prague, No. 20131044 Retention models of the students of the Czech economics faculties. 


\section{REFERENCES}

Aberson, C.L., Berger, D.E., Healy, M.R., and \& Romero V.L., (2002) 'An Interactive Tutorial for Teaching Statistical Power', Journal of Statistics Education, vol. 10, no 3, pp. 1-7. https://doi.org/10.1 $\underline{080 / 10691898.2002 .11910682}$

Blackmon, M., Hong, Y. and Choi, I. (2007) Case-Based Learning. In M. Orey (Ed.), Emerging perspectives on learning, teaching, and technology, [Online], Available: http://epltt.coe.uga.edu/ [23 Apr 2018].

Bobbitt, M. L., Inks, S. K., Kemp, K. J. and Mayo, D. T. (2000) 'Integrating Marketing Courses to Enhance Team-Based Experiential Learning', Journal of Marketing Education, vol. 22, no. 1, pp. 15-24. https://doi.org/10.1177/0273475300221003

Cachia, R. (2008). Social computing: Study on the use and impact of online social networking, [Online], Available: http://publications. jrc.ec.europa.eu/repository/bitstream/111111111/6952/1/ jrc48650.pdf [22 Feb 2018]

Camarero, C., Rodriguez, J. and San Jose, R. (2009) A comparison of the learning effectiveness of live cases and classroom projects, [Online], Available: http://www.heacademy.ac.uk/assets/bmaf/ documents/publications/IJME/Vol8no3/6IJME254.pdf [22 Feb 2018].

Caputo, A., Wolf, P. and Borho, S. (2006) Technology Brief: Digital Media, University of Guelph, [online], Available: http://www. uoguelph.ca/tss/pdfs/TBDigMedia.pdf, [using www.archive.org 08 Aug 2019].

Cole, J. and Foster, H. (2007) Using Moodle, Sebastopol: O'Reilly Media.

Dillenbourg, P. (2000) 'Virtual learning environments: Learning in the new millennium', Proceedings EUN Conference: Learning in the New Millennium: Building New Educations Strategies for Schools, Geneva, pp. 1-30.

Edmondson, A. C. (2013) Teaming to innovate, San Francisco: Jossey-Bass

Elam, E. L. R. and Spotts, H. E. (2004) 'Achieving marketing curriculum integration: A live case study approach', Journal of Marketing Education, vol. 26, no.1, pp. 50-65. https://doi. org/10.1177\%2F0273475303262351

Fraser, S. and Bosanquet, A. (2006) 'The curriculum? That's just a unit outline, isn't it?', Studies in Higher Education, vol. 31, no. 3, pp. 269-284. https://doi.org/10.1080/03075070600680521

Gray, D., Brown, S. and Macanufo, J. (2010) Gamestorming. A Playbook for Innovators, Rulebreakers, and Changemakers, Sebastopol: O'Reilly Media.

Hackbert, P. H. (2006) 'Integrating Active Learning and Cases in Undergraduate Entrepreneurship Classes across the Curriculum', Proceedings of the United States Association for Small Business and Entrepreneurship 2006 Conference (USASBE 2006), Tucson, pp. 1-8.

Hamer, L. O. (2000) 'The Additive Effects of Semistructured Classroom Activities on Student Learning: An Application of Classroom-Based Experiential Learning Techniques', Journal of Marketing Education, vol. 22, no. 1, pp. 25-34. https://doi org $/ 10.1177 \% 2 \mathrm{~F} 0273475300221004$

Hawrylyshyn, B. B. (1967) 'Preparing Managers for International Operations: Role of Management Development', Business Quarterly, vol. 32, no. 3, pp. 28-36.
Hedberg, J. G. (2011) 'Towards a disruptive pedagogy: Changing classroom practice with technologies and digital content', Educational Media International, vol. 48, no. 1, pp. 1-16. https:// doi.org/10.1080/09523987.2011.549673

Hendl, J. (2015) Přehled statistických metod, Prague: Portál.

Hruby, M. (2008) 'Freedom in Adult Education', Journal on Efficiency and Responsibility in Education and Science, vol.1, no. 2 , pp. 12-19.

Huddleston, P. and Unwin, L. (1997) Teaching and learning in further education, diversity and change, London: Routledge.

Joshi, M. P., Davis, E. B., Kathuria, R. and Weidner, C. K. (2003) 'Learning and teaching strategic management through experiential methods', Academy of management proceedings, Seattle, pp. D1D6. https://doi.org/10.5465/ambpp.2003.13792569

Kolb, D. A. (1984) Experiential learning: experience as the source of learning and development. New Jersey: Prentice Hall.

Kolb, A. Y. and Kolb, D. A. (2011) 'A Dynamic, Holistic Approach Education and Development', in Armstrong, S. J. and Fukami, C. V. (eds.) The SAGE Handbook of Management Learning, Education and Development, London: SAGE Publications Ltd, pp. 42-68. https://doi.org/10.4135/9780857021038.n3

Law, K. M. Y., Lee, V. C. S. and Yu, Y. T. (2010) 'Learning motivation in e-learning facilitated computer programming courses', Computers \& Education, vol. 55, no. 1, pp. 218-228. https://doi. org/10.1016/j.compedu.2010.01.007

Mayer, R. (2005) The Cambridge handbook of multimedia learning, New York: Cambridge University Press.

Merseth, K. K. (1991) The Case for Cases in Teacher Education. Washington: Opinion Papers.

O'Reilly, T. (2005) What Is Web 2.0 Design Patterns and Business Models for the Next Generation of Software, [Online], Available: https://www.oreilly.com/pub/a/web2/archive/what-is-web-20. html [24 Mar 2018].

Polackova, J. and Jindrova, A. (2010) 'Innovative Approach to Education and Teaching of Statistics', Journal on Efficiency and Responsibility in Education and Science, vol. 3, no. 1, pp. 14-27.

Simkins, B. J. (2001) An innovative approach to teaching finance: Using live cases in the case course, Oklahoma: Oklahoma State University.

Svec, V. and Kaderabkova, T. (2010) 'Using Experiential Learning in Marketing Communication Course', Proceedings of the $19^{\text {th }}$ International Scientific Conference Agrarian Perspectives, Prague, pp. 257-264.

Svec, V., Ticha, I. and Kaderabkova, T. (2011) 'Learning Experience Through Team Re-Shuffle (Two Years Study)', Conference Proceedings of the International Academy of Business and Public Administration Disciplines (IABPAD), pp. 886-903.

Watson, J. A. and Pecchioni, L. L. (2011) 'Digital Natives and Digital Media in the College Classroom: Assignment Design and Impacts on Student Learning', Educational Media International, vol. 48, no. 4, pp. 307-320. https://doi.org/10.1080/09523987.2 011.632278

Young, M. (1995) Teacher education for the further education sector: Training the lecturer of the future, London: Institute of Education. 